\title{
OBRAMBNA STRATEGIJA V HIERARHIJI STRATEŠKIH DOKUMENTOV S PODROČJA NACIONALNE VARNOSTI REPUBLIKE SLOVENIJE
}

Povzetek Aktualna Obrambna strategija, ki jo je sprejela Vlada Republike Slovenije decembra 2001, je bila izdelana pred več kot desetletjem. Od takrat se je svet zelo spremenil. Dinamika in kompleksnost sodobnih varnostnih razmer sta v sodobnem svetu bistveno bolj prežeti z nepredvidljivostjo, izzivi in problemi, s katerimi se spopada današnji svet, od gospodarske krize prek podnebnih sprememb do boja proti terorizmu, pa so $\mathrm{v}$ medsebojni soodvisnosti in zahtevajo celovito razumevanje družbenih pojavov in procesov. Spremembe v mednarodnem varnostnem okolju pomembno vplivajo tudi na vsebino in dinamiko razvoja nacionalnovarnostnega sistema Republike Slovenije in znotraj njega tudi njenega obrambnega sistema.

V tem kontekstu je v prispevku posebna pozornost namenjena razumevanju sodobnih obrambnih strategij, mestu in vlogi Obrambne strategije Republike Slovenije v nacionalnovarnostnem sistemu ter njenemu razmerju do hierarhično višjih in nižjih strateških dokumentov s področja nacionalne varnosti Republike Slovenije.

Ključne besede

\section{Strategija, hierarhija strateških dokumentov, obrambna strategija, nacionalno- varnostna strategija.}

The current Defence Strategy adopted by the Government of the Republic of Slovenia in December 2001, was drafted over a decade ago. However, the world has changed significantly since then. The dynamics and complexity of the modern security situation have become much more unpredictable, while the challenges and problems encountered by today's world, i.e. the economic crisis, climate changes, counterterrorism etc., are interdependent and demand a comprehensive understanding of social phenomena and processes. The changes in the international security environment have an important impact on the contents and dynamics of the national security system development in the Republic of Slovenia including its defence system. 
With this in mind, the article devotes special attention to the understanding of modern defence strategies, the place and the role of Defence Strategy of the Republic of Slovenia in the national security system and its relation to hierarchically superior and inferior strategic documents regulating the national security system of the Republic of Slovenia.

Key words Strategy, hierarchy of strategic documents, defence strategy, national security strategy.

Uvod Obrambni sistem Republike Slovenije se je od leta 2001 do 2009 razvijal predvsem na podlagi strateških razvojno-usmerjevalnih dokumentov s področja nacionalne varnosti in obrambe, ki so bili oblikovani na začetku tretjega tisočletja, v obdobju vključevanja Republike Slovenije v evro-atlantske integracije. Vrzel, ki je nastala z zastarelimi strateškimi razvojno-usmerjevalnimi dokumenti, doseženo stopnjo razvoja obrambnega sistema, sprejetimi obveznostmi do Nata in EU ter nacionalnimi prednostmi razvoja obrambnega sistema, je zahtevala nove, objektivnejše in realnejše strateške podlage za izvajanje obrambnih reform. Na podlagi te ocene je Ministrstvo za obrambo v prvi polovici leta 2009 izvedlo Strateški pregled obrambnega resorja. Med njegovimi ključnimi ugotovitvami je bilo izpostavljeno, da je treba pregledati, dopolniti in medsebojno uskladiti temeljne strateške in razvojne dokumente s področja nacionalne varnosti.

Resolucija o strategiji nacionalne varnosti Republike Slovenije (v nadaljevanju: ReSNV) je skladno s hierarhijo dokumentov temeljni razvojno-usmerjevalni dokument na področju nacionalne varnosti RS in tako tudi prvi izmed dokumentov s tega področja, ki je bil sprejet v Državnem zboru 26. marca 2010. Usklajenost in medsebojna vsebinska povezanost temeljnih dokumentov na področju nacionalne varnosti se lahko nadaljujeta s pripravo nove Obrambne strategije, ki jo sprejema Vlada RS.

Prispevek v ospredje postavlja mesto in vlogo obrambne strategije v hierarhiji strateških dokumentov s področja nacionalne varnosti. Prvi del prispevka temelji na teoretičnih izhodiščih razumevanja strategije kot pojma ter hierarhičnem razmerju strateških dokumentov s področja nacionalne varnosti v Republiki Sloveniji. V drugem, praktičnem delu, je predstavljena primerjalna analiza sodobnih obrambnih strategij izbranih držav, ki obsega tudi bistvena priporočila za pripravo nove slovenske obrambne strategije. Reprezentativni vzorec izbranih držav je nastal na podlagi teh meril: velikosti države (teritorialne/demografske), članstva v Natu/EU, tradicije obstoja nacionalnovarnostnih sistemov zahodnoevropskih držav, države v procesu približevanja evroatlantskim integracijam (t. i. države Zahodnega Balkana) in sprejetja obrambne strategije po letu 2005. Izkustva drugih držav v tem kontekstu predstavljajo pomemben primarni primerjalni vir, saj je vsaka država tako glede teoretičnega kot tudi praktičnega reševanja vprašanj na nacionalnovarnostnem področju svojevrsten primer. 


\section{STRATEGIJA KOT POJEM}

Etimologija izraza strategija izhaja iz grških besed stratos (vojska) in ago (voditi), kar pomeni umetnost vojskovanja. Strategija je s tega vidika znanost in veščina (teorija in praksa) o pripravah in vodenju vojne in uporabi sile za doseganje političnih, ekonomskih in vojaških ciljev. S strategijo se ukvarjajo v najvišjem političnem, državnem in vojaškem vodstvu, njena osnovna vsebina sta priprava in vodenje oboroženega boja in vojne (Javornik (ur.), 1998, str. 4117).

V priročniku US Army War Collegea so strategijo na državni ravni definirali kot veščino in znanstveno disciplino razvijanja ter uporabe političnih, ekonomskih, socialno-psiholoških in vojaških zmogljivosti države za ustvarjanje strateških učinkov za zaščito oziroma razvoj nacionalnih interesov, skladno s političnimi smernicami. Strategija pri tem išče sinergijo in simetrijo med cilji, koncepti in viri, da bi povečala verjetnost ter pozitivne posledice političnega uspeha in zmanjšala možnosti za neuspeh (Yarger, 2006, str. 65-67).

Strategija izhaja zlasti iz strateškega okolja, kulturnega okolja in vrednostnega sistema ter zahteva celovit pristop. Razumevanje strategije nam pove, kako (koncept ali način) bo politično vodstvo države uporabilo svojo moč (vire ali sredstva), ki jo ima na voljo, da bo vzpostavilo nadzor (vpliv) nad stanjem oziroma področji (geografskimi), da bi zaščitilo interese in doseglo cilje skladno z nacionalno politiko.

Torej lahko izpostavimo, da je namen strategije razjasnitev, vplivanje, upravljanje oziroma razreševanje spremenljivosti, nepredvidljivosti, kompleksnosti in nejasnosti ${ }^{1}$ strateškega okolja z identifikacijo in doseganjem (ustvarjanjem) strateških učinkov v podporo političnim ciljem. V vsaki strategiji torej prevladuje njen politični namen, kljub splošnosti dokumenta pa so v njej tudi temeljna izhodišča za planiranje.

\section{HIERARHIJA IN MEDSEBOJNA RAZMERJA STRATEŠKIH DOKUMENTOV S PODROČJA NACIONALNE VARNOSTI V REPUBLIKI SLOVENIJI}

Med številnimi predpostavkami o strategiji je za razumevanje vloge, pomena in medsebojnih razmerij med posameznimi strateškimi dokumenti na področju nacionalne varnosti ter obrambe zelo pomembna tista, ki pravi, da je strategija hierarhična. Tako kot je strategija podrejena politiki, so nižje nivojske strategije podrejeni višji nivojski strategiji. Hierarhičnost omogoča strategiji razpon nadzora (Yarger, 2006, str. 65-67).

Hierarhičnost zagotavlja tudi logičen način delegiranja odgovornosti, pristojnosti in sledljivosti v okviru vodstva. Prav tako nakazuje, da morajo sestavni deli strategije, to so cilji, načini in viri, biti primerni ravni strategije in medsebojno skladni. Politično vodstvo si zagotavlja in vzdržuje svoj nadzor in vpliv nad instrumenti moči $\mathrm{s}$ hierarhično naravo državne strategije. Splošno gledano strategija izhaja z vrha kot

\footnotetext{
1 Predstavljen namen strategije izhaja iz angleške kratice VUCA (Volatility, Uncertainty, Complexity and Ambiguity).
} 
posledica neke velike ali splošne strategije, za katero ni nujno, da je javno dokumentirana, strategije nacionalne varnosti in drugih nacionalnih (področnih) strategij in političnih stališč do posebnih zadev. Nacionalna politika tako zagotavlja širše strateške smernice za politično vodstvo in splošno oblikuje nacionalni interes glede na posebne strateške okoliščine.

Strategija mora zagotoviti pravilen odnos oziroma razmerje med zadanimi cilji, uporabljenimi sredstvi oziroma načini za doseganje teh ciljev ter razpoložljivimi viri za doseganje ciljev na vseh ravneh (hierarhično). To pomeni, da morajo biti cilji, načini in sredstva usklajeni tako kvalitativno kot kvantitativno ter navzven in navznoter. Tako npr. doseganje ciljev iz strategije nacionalne varnosti zahteva uporabo instrumentov moči, ki jih ima na razpolago država - kvalitativno vprašanje pri tem je, ali bo doseganje določenih ciljev dalo želeni strateški učinek in ali ti učinki upravičujejo cilj, uporabljene metode, potrebne vire ter druge (družbene in politične) stroške.

V Republiki Sloveniji nimamo posebnega zakona o nacionalni varnosti. Zagotavljanje nacionalne varnosti Republike Slovenije, kot je to zapisano v ReSNV 2010, temelji na Ustavi Republike Slovenije, spoštovanju človekovih pravic in temeljnih svoboščin ter demokracije in načel pravne države. Pri tem se upoštevajo sprejeti nacionalni razvojni dokumenti, zakonski in podzakonski akti in spoštujejo načela mednarodnega prava ter pravice in obveznosti Republike Slovenije, prevzete z mednarodnimi pogodbami.

Dokumente s področja nacionalne varnosti razvrstimov skupine predvsem na podlagi dveh meril: vsebinske širine dokumenta in temeljnega namena. Vsebinska širina dokumenta omogoča razlikovanje med nacionalnovarnostnimi, obrambnimi, vojaškoobrambnimi in civilnoobrambnimi dokumenti ter dokumenti s področja zaščite in reševanja, medtem ko gre pri namenu dokumenta predvsem za poslanstvo, ki ga je dokumentu namenil njegov izdajatelj (Ferfila, 2003, str. 328-329, Bebler \{et al\}, 1999, str. 17).

Na podlagi omenjene klasifikacije lahko uvrstimo tudi različne strateške dokumente $\mathrm{s}$ področja nacionalne varnosti $\mathrm{v}$ Republiki Sloveniji. ReSNV lahko glede na vsebinsko širino uvrstimo med nacionalnovarnostne dokumente. Obrambno strategijo pa bi na podlagi klasifikacije lahko opredelili kot obrambni dokument, saj po vsebini presega naravo vojaškoobrambnega dokumenta.

$\mathrm{ReSNV}^{2}$, kot je zapisano $\mathrm{v}$ njenem uvodu, je temeljni razvojno-usmerjevalni dokument na področju nacionalne varnosti, ki določa najširše sistemsko-organizacijske rešitve celovitega delovanja države pri zagotavljanju nacionalne varnosti. Pri tem je posebej poudarjeno, da je resolucija izhodišče za pripravo in dopolnjevanje

\footnotetext{
2 ReSNV spada med splošne (nacionalne) strategije, pri čemer gre za sistem znanstvenih spoznanj (teorija) in znanost, ki preučuje najpomembnejša vprašanja v zvezi s teorijo in prakso obrambne dejavnosti države, predvsem uporabo njenih političnih, gospodarskih, psiholoških, vojaških ter drugih sredstev in zmogljivosti pri uresničevanju nacionalnih obrambnih ciljev zaradi zavarovanja nacionalnih interesov v miru in vojni. Bistvo tovrstne strategije torej je, da na temelju opredeljenih nacionalnih interesov in presoje zunanje ogroženosti teh interesov določi strateške cilje, zbere razpoložljive vire in ob upoštevanju tveganj in stroškov odkrije optimalni način (»strategijo«) za uresničitev postavljenih ciljev (Bebler \{et al\}, 1999, str. 12-14).
} 
posebnih strateških in drugih razvojnih ter doktrinarnih dokumentov na področju nacionalne varnosti in za normativno, organizacijsko in drugo vsebinsko urejanje vprašanj v zvezi z zagotavljanjem nacionalne varnosti Republike Slovenije.

Obrambna strategija Republike Slovenije ${ }^{3}$ spada med obrambne razvojno-usmerjevalne dokumente, izhaja iz hierarhično višjega dokumenta, tj. ReSNV, in določa smernice ne le za razvoj celotnega obrambnega sistema, temveč tudi vseh družbenih zmogljivosti za potrebe obrambe države oziroma njenih interesov in ciljev. Tako se zagotavlja usklajen razvoj vojaških in civilnih obrambnih zmogljivosti Republike Slovenije. Obrambna strategija predstavlja podlago za pripravo ter spreminjanje in dopolnjevanje normativnih, doktrinarnih in drugih dokumentov na obrambnem področju ter urejanje različnih vsebinskih vprašanj v zvezi z obrambo Republike Slovenije.

Pri oblikovanju posameznih strateških dokumentov s področja nacionalne varnosti je zato bistveno, da se upoštevata načelo hierarhije dokumentov in zaporedje njihovega nastajanja. Tako se $\mathrm{v}$ strateške dokumente $\mathrm{s}$ področja nacionalne varnosti vnašajo ustaljenost, red, hierarhična usklajenost in ne nazadnje krepi tudi njihov pomen $\mathrm{v}$ družbi. Spodnja shema prikazuje sprejete strateške dokumente v Republiki Sloveniji na področju nacionalne varnosti in njihovo hierarhično razmerje (glej shemo 1).
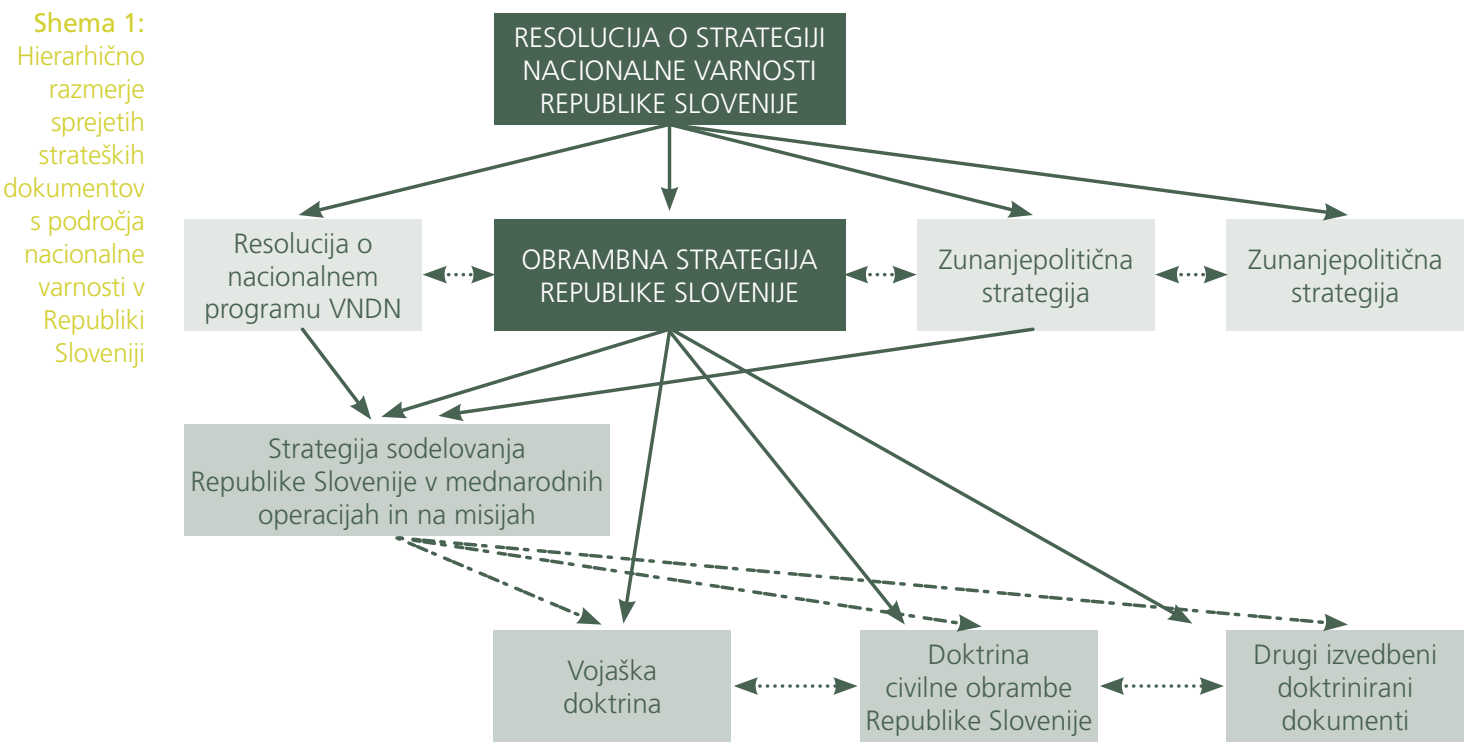

Legenda:

$\longrightarrow$ razmerje »nadrejenosti in »podrejenosti

vzajemni vsebinski vpliv

-.- vsebinski vpliv

3 Obrambna strategija je veščina in znanost razdelitve in uporabe obrambnih zmogljivosti in vojaške moči za doseganje nacionalnih ciljev v miru in vojni. Pri tem gre za dejavnost predvsem najvišjega politično-obrambnega in vojaškega vodstva države v zvezi s pripravami in izvajanjem (nacionalne) obrambe zaradi uresničevanja obrambnih in vojaških ciljev države. Tudi obrambna strategija se ukvarja predvsem z iskanjem optimalnega razmerja med viri in cilji, zmogljivostmi in nameni ter $z$ iskanjem optimalnega načina uporabe razpoložljivih virov zaradi uresničitve postavljenih ciljev, pri tem pa se omejuje na obrambno prvino nacionalne varnosti. 


\section{ANALIZA OBRAMBNIH STRATEGIJ IZBRANIH DRŽAV}

V primerjalno analizo obrambnih strategij je bilo vključenih šest držav (Češka, Kanada, Srbija, Španija, Velika Britanija in ZDA), in sicer na podlagi teh meril:

- zahodnoevropske demokracije z izoblikovanimi in stabilnimi nacionalnovarnostnimi sistemi,

- nove članice Nata in EU,

- države, ki so v procesu vključevanja v evro-atlantske integracije (t. i. države Zahodnega Balkana),

- obrambne strategije držav, ki imajo sodoben pristop na obrambnem področju in odražajo grožnje, tveganja in izzive 21. stoletja.

Analiza obrambnih strategij izbranih držav je bila izvedena na podlagi induktivne metode preučevanja, saj so bile najprej izvedene kvalitativne analize posameznih dokumentov držav (posamično), v naslednji fazi pa je bila izvedena še primerjalna analiza, ki v tabelarnem prikazu ${ }^{4}$ po posameznih izbranih parametrih in dodatnih obrazložitvah analizira podobnosti, razlike in posebnosti v posameznih dokumentih izbranih držav (splošno).

\subsection{Kvalitativna analiza obrambnih strategij izbranih držav}

Kvalitativna analiza obrambnih strategij izbranih držav zajema ključne poudarke po posameznih izbranih parametrih, predvsem v smislu poudarjanja njihovih oblikovnih konceptov strukturiranosti obrambne strategije, hierarhične umeščenosti in namena strategije ter pogostosti in postopka sprejemanja strategije. Vsebinski poudarki analize se nanašajo na obrambno politiko, koncepte obrambe (nacionalna obramba : kolektivna varnost in obramba), strukturo in organiziranost obrambnih sistemov, celovitost pristopa k zagotavljanju obrambe, smernice za oblikovanje ravni ambicij vojaškega delovanja, načine opredeljenosti obrambnih virov in povezavo z obrambnim planiranjem.

Pri vsaki analizi strategije so navedeni tudi njena prednostna področja razvoja $\mathrm{v}$ prihodnje in posebnosti, ki so bile ugotovljene ob preučevanju in izhajajo iz strukturiranosti sistema nacionalne varnosti posameznih držav. Glede na to, da so preučevani dokumenti aktualni in razkrivajo prihodnje smeri razvoja obrambnih sistemov preučevanih držav, so bili, tam kjer je bilo to mogoče, v kvalitativno analizo po državah vključeni tudi nekateri vsebinski poudarki: obrambno-politični cilji, raven ambicij, naloge oboroženih sil ipd.

\subsection{1 Češka: "The Military Strategy of the Czech Republic 2008«}

\section{$\underline{\text { A. Oblikovno }}$}

Obrambna strategija, ob upoštevanju določila Strateškega koncepta Nata 1999, CPG 2006 in Evropske varnostne strategije 2003, izhaja iz Varnostne strategije Republike Češke. Pristop k izdelavi je sodoben in pronatovsko usmerjen, besedilo pa kratko,

4 Tabelarni prikaz je zaradi obsega prispevka na razpolago v uredništvu revije in pri avtorjih. 
zgolj na devetih straneh z 21 točkami ali členi. Vsebina dokumenta je veliko konkretnejša v delih, ki se nanašajo na politično-vojaške cilje, v delu, ki se nanaša na razvoj oboroženih sil in njihovih zmogljivosti, pa hkrati tudi dovolj splošna, s čimer pušča dovolj vsebinskega prostora planskim dokumentom.

\section{B. Vsebinsko}

V poglavju o obrambni strategiji je dokument strukturno in vsebinsko podoben deklaraciji. V njem je najprej opisano varnostno okolje z razvrstitvijo groženj glede na stopnje učinkovanja.

Varnostni interesi Češke so tesno povezani z interesi Nata in EU, njena zmožnost učinkovitega in uspešnega odzivanja na grožnje in tveganja nacionalne varnosti pa je odvisna predvsem od mednarodnega sodelovanja. Skladno s tem obrambna politika Češke temelji na dejavnem sodelovanju v aktivnostih Nata in EU ter na sodelovanju, prispevanju in tvornem delovanju v drugih mednarodnih organizacijah (OZN, OVSE) in iniciativah.

Učinkovit in kredibilen sistem zagotavljanja nacionalne obrambe Češke temelji na aktivni udeležbi v Natovem sistemu kolektivne obrambe in močni transatlantski povezanosti. Takšna zunanjepolitična drža države ${ }^{5} \mathrm{v}$ okoliščinah spremenljivega mednarodnega varnostnega okolja zahteva aktivno sodelovanje čeških oboroženih sil v mednarodnih operacijah in na misijah pod okriljem OZN, Nata ali EU. Z aktivnim sodelovanjem v teh operacijah si Češka zagotavljala svoje varnostne interese in uravnotežen razvoj oboroženih sil. Njihova učinkovitost temelji na zmožnosti takojšnjega odzivanja na krizne situacije in celostnem pristopu v smislu civilno-vojaškega sodelovanja.

V strategiji je izpostavljeno tudi povečevanje obrambnega proračuna, da bo Češka sposobna uresničiti zadane varnostno-obrambne cilje, izvesti potrebno modernizacijo vojaške opreme in oborožitve, zadovoljiti standarde usposabljanja in infrastrukturnih investicij ter zagotavljati obseg in stopnjo angažiranja Češke v aktivnostih Nata in EU.

Poslanstvo čeških oboroženih sil je razvrščeno v štiri sklope nalog:

1. sodelovanje oboroženih sil zunaj ozemlja - skladno s prizadevanji mednarodne skupnosti (operacije v okviru Nata, EU, OZN oziroma v okviru koalicij z mandatom OZN),

2. sodelovanje pri kolektivni obrambi - Češka bo zagotavljala kopenske in zračne sile iz nabora sil, določenih v Natovem procesu obrambnega planiranja,

\footnotetext{
5 Poleg tega je pri tem treba upoštevati tudi njihov prispevek $k$ varnosti na področju razorožitve in nadzora nad razoroževanjem ter interes za sodelovanje v Natovem projektu postavitve balistične raketne obrambe proti raketam, ki bi lahko bile potencialne nosilke orožij za množično uničevanje.
} 
3. sodelovanje v vojaških operacijah zunaj 5. člena Washingtonske pogodbe skladno z ravnijo ambicij ${ }^{6}$ je Češka pripravljena aktivno prispevati k operativnim nalogam, ki se nanašajo na izvajanje bojnih operacij ter nalog humanitarne pomoči in postkonfliktne stabilizacije ter obnove,

4. sodelovanje pri podpori civilnim oblastem $\mathrm{v}$ kriznih razmerah - oborožene sile bodo zagotavljale podporo integriranemu sistemu zaščite in reševanja ter bodo po potrebi dopolnjene $\mathrm{z}$ aktivnimi rezervnimi silami ${ }^{7}$.

Strategija razvoja čeških oboroženih sil temelji na skupnih načelih: enotnem naboru sil, učinkovitosti, premestljivosti, združenem delovanju, povezljivosti, modularnosti, koordinaciji z zunanjimi akterji, mednarodnem sodelovanju in kompetentnem osebju.

\subsubsection{Kanada: „Canada First Defence Strategy 2006“}

\section{$\underline{\text { A. Oblikovno }}$}

Naziv dokumenta je »prva« kanadska obrambna strategija, ki poleg političnih usmeritev obrambne strategije predstavlja tudi 20-letni plan preoblikovanja kanadskih oboroženih sil. Temelji na štirih ključnih stebrih izgradnje zmogljivosti ter priložnosti za obrambno industrijo. Strategija tako ne bo prispevala samo k večji varnosti prebivalcev, temveč pomeni tudi gospodarske koristi za celotno državo, za učinkovitejše doseganje zahtev obrambnih nabav tako na nacionalni kot tudi globalni ravni.

Gre za t. i. celostno strategijo, ki je zgrajena na viziji vlade in ocenah prihodnjega varnostnega okolja. Njen cilj je preoblikovati kanadske oborožene sile v moderno vojsko in hkrati oblikovati temelje za bolj integrirano, prilagodljivo in zmogljivo silo. Strategija tako zagotavlja tudi planska izhodišča, ki omogočajo vladi preoblikovati kanadske oborožene sile v t. i. vojsko state-of-the art ${ }^{8}$.

Oblikovno je strategija napisna na 21 straneh in obogatena s shematskimi, tabelarnimi in slikovnimi prikazi. Vsebuje pa tudi povzetek, ki na dveh straneh daje jasno politično sporočilo in poudarke prihodnjega razvoja in vloge kanadskih oboroženih sil. Potek strategije preoblikovanja kanadskih oboroženih sil je mogoče prikazati tudi s shemo:

\footnotetext{
${ }^{6}$ Raven ambicij sodelovanja v hkratnih vojaških operacijah je izražena s štirimi vrstami namenskih sil: (1) namenska sila velikosti brigade za obdobje šestih mesecev brez rotacije, (2) vzdržljiva namenska sila velikosti bataljona v šestmesečni rotaciji, (3) vzdržljiva namenska sila velikosti čete v šestmesečni rotaciji, (4) namenska sila $v$ stopnji pripravljenosti do velikosti bataljona, določena za NRF ali EUBG, in sicer takrat, kadar namenska sila velikosti brigade ni na operaciji.

7 Rezerva se zagotavlja iz aktivne rezerve, ki obsega prostovoljce, ki podpišejo triletno pogodbo s pristojnim regionalnim vojaškim poveljstvom (skupno $13+$ Praga). Pripadniki aktivne rezerve brez predhodnega opravljanja vojaške službe opravijo osemtedensko usposabljanje v času prvega leta ter do tri tedne v drugem in tretjem letu služenja. Pripadniki s predhodno opravljenim vojaškim služenjem opravijo vsako leto tritedensko vojaško usposabljanje. Aktivna rezerva je namenjena podpori regularnim oboroženim silam vizrednem stanju, vojni ali naravnih nesrečah (podatkovna baza Jane's ARMY, Czech Republic z dne 20. 2. 2008).

s Vojska z najvišjo mogočo stopnjo razvoja in tehnološke sofisticiranosti ipd.
} 


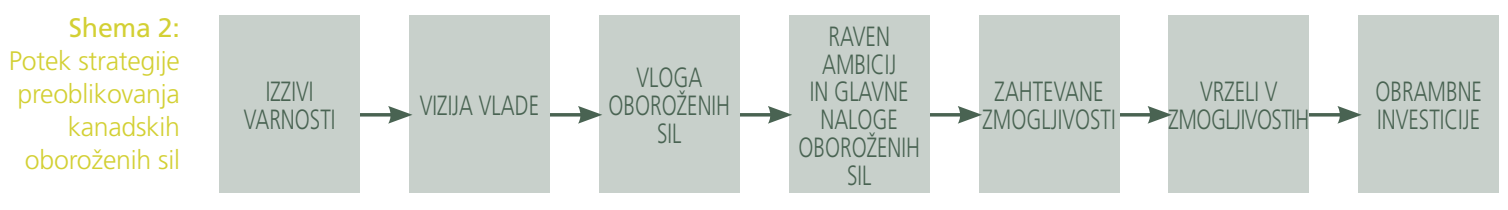

\section{B. Vsebinsko}

V strategiji je izpostavljeno, da po koncu hladne vojne in v času mirovne dividende kanadske oborožene sile niso bile deležne ustreznega zagotavljanja obrambnih virov, kar se je odražalo v nepripravljenosti za učinkovito soočanje z izzivi kompleksnega in dinamičnega globalnega okolja. Zato izzivom na nacionalnem ozemlju strategija posveča največ pozornosti, zlasti poplavam, požarom, hurikanom in potresom, ki lahko prerastejo sposobnost lokalnih zmogljivosti. Drugi izpostavljeni izzivi, pri katerih bodo oborožene sile izvajale podporo, so terorizem, nedovoljena trgovina $\mathrm{z}$ belim blagom, tuje poseganje v naravne vire in pandemije. Prav tako bodo oborožene sile pomagale varovati občutljivo arktično območje oziroma suverenost Kanade na tem območju.

Glede na določeno raven ambicij strategija navaja šest glavnih nalog, ki jih bodo morale kanadske oborožene sile v prihodnje izvajati na območju Kanade, v Severni Ameriki ali globalno, in sicer:

1. dnevno izvajanje aktivnosti na ozemlju Kanade in na kontinentu Severne Amerike ali prek NORAD 9 ,

2. podpora večjim javnim dogodkom v Kanadi,

3. odziv na večji teroristični napad,

4. podpora civilnim oblastem v kriznih razmerah, kot so naravne nesreče,

5. vodenje ali sodelovanje v večjih mednarodnih operacijah in na misijah za daljše časovno obdobje,

6. premeščanje sil na območja kriz za krajša časovna obdobja kot odziv na razmere po svetu.

Za uresničevanje teh nalog bodo morale biti oborožene sile integrirane, fleksibilne, večnamenske in sposobne izvajanja vojaškega bojevanja ter sodelovanja s civilnimi obrambnimi zmogljivostmi.

Kanadska vlada predvideva $\mathrm{v}$ naslednjih 20 letih zagotoviti stabilno zagotavljanje virov za razvoj oboroženih sil, kamor spadajo obrambni proračun in obrambni izdatki. Strategija se bo implementirala skozi strateški investicijski plan. Skupaj naj bi v 20 letih Kanada namenila za obrambo več kot 309 milijard evrov, s čimer bo omogočeno tudi dolgoročno planiranje in doseganje prihodnjih zahtev.

\footnotetext{
9 North American Aerospace Defence Command ali Severnoameriško poveljstvo za obrambo zračnega prostora, ki je bilo s pogodbo ustanovljeno leta 1958, z obnovitvijo pogodbe leta 2006 pa je poveljstvo pridobilo še vlogo pomorskega opozarjanja.
} 
Razmerje med kategorijami razporeditve deležev obrambnih izdatkov za osebje, opremo in infrastrukturo ter druge izdatke bodo poskušali uravnotežiti tako, da bodo izdatke za osebje znižali pod $50 \%$, povečali pa jih bodo za investicije in operacije. Za povečane izdatke večjih operacij bo vlada namenila ločen fond financiranja.

Uravnoteženo investiranje se bo izvajalo v okviru štirih ključnih stebrov zmogljivosti, in sicer:

1. Kadri - zaradi kadrovskega primanjkljaja in vedno večjih zahtev od oboroženih sil bo Kanada povečala svoj obseg na 70.000 pripadnikov regularnih pripadnikov (prej 64.000) in na 30.000 pripadnikov rezervnih sil (prej 26.000) oziroma skupno za 10.000 pripadnikov.

2. Oprema - zaradi obrambne dividende v letih po koncu hladne vojne so bile degradirane tudi nabave nove opreme, zato za izvajanja sodobnih operacij in obsega nalog oboroženih sil v kompleksnem in nepredvidljivem okolju potrebujejo robustno in sodobno opremo.

3. Pripravljenost - okrepiti splošno stanje pripravljenosti kanadskih sil za operacije zunaj njenega ozemlja ter njihovo zmožnost vzdrževanja, kar bo doseženo z izboljšanjem kadrovskega usposabljanja.

4. Infrastruktura - izboljšanje in modernizacija obrambne infrastrukture (v desetih letih bo zamenjano $25 \%$ oziroma v dvajsetih letih skoraj polovica zdajšnje infrastrukture).

\section{NALOG}

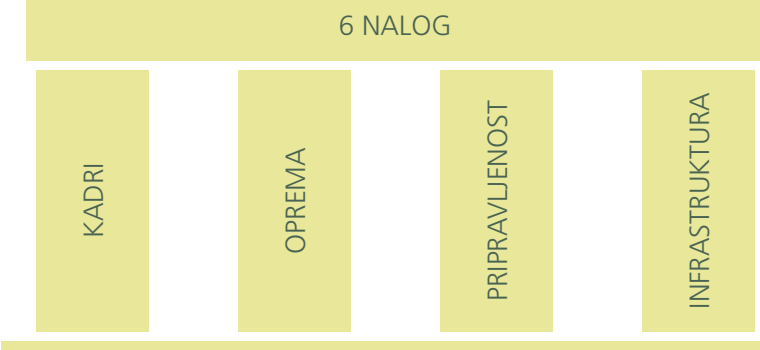

SODOBNA VOJSKA 21. STOLETJA

Za implementacijo ključnih zmogljivosti je vlada na podlagi strategije sprejela večletni Strateški investicijski plan (SIP), ki bo Ministrstvu za nacionalno obrambo pomagal izvajati strategijo z upravljanjem kompleksnosti pri uravnovešanju razporejanja virov med štirimi stebri zmogljivosti, vključno z zaporedjem ključnih projektov. SIP bo omogočal združitev zahtev financiranja v celotnem ministrstvu $\mathrm{v}$ enoten in pregleden plan ter zagotovil ustreznost časovno usklajenih večjih investicij $\mathrm{z}$ razpoložljivimi sredstvi. 
Strategija omogoča razviti kanadski vladi močnejše sodelovanje in vzajemno korist z obrambno industrijo prav zaradi dolgoročnega in stabilnega financiranja. Strategija ustvarja temelje tudi za izdelavo vladne strategije za znanost in tehnologijo, posredno pa bodo imele pri raziskavah in razvoju koristi tudi univerze in fakultete, manjša podjetja pa bodo imela možnosti za uveljavitev na zunanjem trgu v specifičnih tehnologijah.

\subsubsection{Srbija: „Strategija odbrane Republike Srbije 2009«}

\section{$\underline{\text { A. Oblikovno }}$}

Pristop k izdelavi 15 strani dolge strategije je na eni strani sodoben, saj upošteva trenutne varnostne okoliščine in razmere $\mathrm{v}$ mednarodnem varnostnem okolju, tudi vidik svetovne gospodarsko-finančne krize, na drugi strani pa še vedno vključuje bistvene elemente (strukturo in organiziranost delovanja obrambnega sistema), ki jih zahodne demokracije ne vključujejo v tovrstne strateške dokumente.

Kot posebnost strategije se lahko razume njeno poudarjanje suverenosti in celovitosti srbskega teritorija. Strategija zavrača možnost mednarodnega vpletanja v nacionalne pristojnosti neodvisne in suverene države Srbije. Tudi sicer strategija večkrat izpostavlja, da bo Srbija delovala skladno z načeli mednarodnega prava in načeli OZN.

Njena posodobitev je predvidena skladno z varnostnimi razmerami in drugimi dejavniki, ki vplivajo na varnost Srbije. Sprejela jo je Narodna skupščina (parlament).

\section{B. Vsebinsko}

Pristop k opredeljevanju kompleksnega, dinamičnega in medsebojno povezanega globalnega varnostnega okolja $\mathrm{v}$ razmerah informacijske tehnologije ter tudi $\mathrm{z}$ vidika vplivanja svetovne gospodarsko-finančne krize je sodobno predstavljen. Pri tem izstopata dva vsebinska poudarka, in sicer:

- praksa intervencionizma in vmešavanje v notranje zadeve suverenih držav, ki ruši mednarodnopravni red in predstavlja resno grožnjo globalnemu miru in stabilnosti, še posebno, če so podprti z legitimiteto le določenega števila držav ali organizacij mednarodne skupnosti (OZN),

- z vidika nevarnosti, s katerimi se sooča sodoben svet, kažejo na globoko medsebojno soodvisnost držav, regij in na nedeljivost mednarodne varnosti, kar še veliko bolj kaže na potrebo po krepitvi načela sodelovanja in kooperativnega pristopa ${ }^{10} \mathrm{k}$ obrambi in varnosti nacionalnih držav.

V regionalnem varnostnem okolju je poudarek na evroatlantskih integracijah in prizadevanjih Srbije za vključevanje vanje ter sodelovanje v drugih regionalnih pobudah - predvsem v smeri intenziviranja procesa vzpostavljanja demokratičnih

\footnotetext{
${ }_{10}$ "Osnovo kooperativnega pristopa predstavljajo dialog, partnerstvo in skupno delovanje držav ter drugih subjektov v mednarodni skupnosti pri doseganju, ohranjanju in vzpostavljanju miru. Takšen koncept predpostavlja usklajene aktivnosti na področju varnosti, obrambe, politike, gospodarstva in predstavlja pomemben prispevek h krepitvi miru in stabilnosti v mednarodni skupnosti« (Obrambna strategija Srbije 2009).
} 
standardov. V tem delu strategija opisuje pomen kolektivne obrambe v okviru Nata in programa PzM, v katerem sodeluje tudi Srbija.

Iz usmeritev obrambne politike izhajajo cilji (med katerimi je tudi integracija v Nato in EU), iz njih pa naloge obrambne politike. Skozi strateški koncept obrambe so izpostavljene temeljne usmeritve Srbije glede angažiranja razpoložljivih virov za ohranitev in zaščito njenih obrambnih interesov s poudarkom na totalni obrambi, $\mathrm{v}$ kateri integralno sodelujejo vsi subjekti obrambe, in ob vse večjem poudarku na sodelovanju s partnerji in mednarodnem sodelovanju.

Obrambni sistem upravljajo narodna skupščina, predsednik države, vlada in Ministrstvo za obrambo, za katere so navedene tudi pristojnosti za področje upravljanja obrambnega sistema. Navedenih je 11 temeljnih načel delovanja obrambnega sistema, ki temeljijo na zakonodajnih izhodiščih, mednarodnem pravu in določilih OZN.

Temeljni obrambni viri se delijo na kadrovske in materialne, njihovo angažiranje pa ureja zakon. Kadrovskega ustvarja demografski potencial, materialni pa obsegajo naravne, nacionalne, finančne, informacijske, tehnično-tehnološke in druge potenciale Srbije, ki se angažirajo za potrebe obrambe. Pri tem izpostavljajo tudi pomen planiranja in angažiranja državnih rezerv ter sodelovanja z namensko, obrambno industrijo.

Obrambno planiranje ima primarno vlogo v procesu upravljanja obrambnega sistema. S sistemom planiranja se določajo delovanje in razvoj obrambnega sistema, vzpostavitev potrebnih zmogljivosti, racionalno razporejanje razpoložljivih finančnih sredstev ter transparentno razpolaganje z obrambnimi viri. Na podlagi strateških izhodišč in potrjenih potreb se prek sistema $\mathrm{PPBS}^{11}$ in izdelanih programov razvoja neposredno določi upravljanje obrambnih virov, usmerjenih v vzpostavitev zmogljivosti za posamezne naloge in aktivnosti (operacije).

\subsection{4 Španija: „National Defense Directive 01/2008«}

\section{$\underline{\text { A. Oblikovno }}$}

Naziv dokumenta je Nacionalna obrambna direktiva za leto 2008, ki je nastala na podlagi predhodne Direktive iz leta 2004, ta pa izhaja iz Strateškega pregleda obrambe iz leta 2003. Na podlagi leta 2005 sprejetega Temeljnega zakona o nacionalni obrambi ima predsednik vlade pristojnost, da usmerja obrambno politiko, določa njene cilje in oblikuje nacionalne obrambne direktive. Vsaka naslednja direktiva tako predstavlja novosti pri oblikovanju obrambne politike.

Nacionalna obrambna direktiva $\mathrm{v}$ uvodu pojasnjuje, da predstavlja temelje za nacionalnovarnostni sistem in je skladna $\mathrm{z}$ dokumenti mednarodnih organizacij, v katerih deluje Španija kot članica. Direktiva se dopolnjuje po potrebi, njeno vodilo pa je,

\footnotetext{
"I Planning-Programming and Budgeting System je sistem, ki združuje planiranje, programiranje in financiranje.
} 
da mora biti osredotočena na celostni pristop pri zagotavljanju varnosti in obrambe. Iz tega izhaja, da Španija pri oblikovanju strateških dokumentov z obrambnega področja izhaja iz t. i. bottom-up pristopa, medtem ko njihova implementacija temelji na t. i. top-down pristopu.

\section{B. Vsebinsko}

Struktura direktive sledi logičnemu zaporedju od splošnega k posebnemu. V drugem poglavju so poleg opisanih groženj ter ključnih interesov in ciljev navedena tudi ključna interesna področja ter organizacija delovanja Španije na mednarodnem področju. Iz interesov in ciljev $\mathrm{v}$ četrtem poglavju izhajajo splošne smernice delovanja obrambne politike.

Španija se na mednarodnem področju zavzema za spoštovanje načel OZN, spodbujanje razvoja vojaških in civilnih zmogljivosti v okviru EVOP, spodbujanje izvajanja ukrepov, ki krepijo zaupanje in varnost pod okriljem OVSE, ter podporo razvoju ustreznih vojaških zmogljivosti Nata, prek katerih si zagotavlja varnost in obrambo. Izpostavljena so tudi območja Sredozemlja, Latinske Amerike, Sub-saharske Afrike in azijsko-pacifiško območje, ki ravno tako pomembno vplivajo na njeno varnost. V tem kontekstu je poudarjena tudi vloga oboroženih sil, ki morajo razvijati zmogljivosti za učinkovito odzivanje na sodobne vire ogrožanja in tveganja nacionalne varnosti.

Direktiva opredeljuje splošne okvire obrambne politike, ki je usmerjena zlasti v:

- enotno delovanje države na področju obrambe in varnosti,

- vzdrževanje mednarodnega miru in varnosti ter spoštovanje načel mednarodnega prava,

- družbeno in parlamentarno podporo za izvajanje obrambne politike,

- spoštovanje mednarodnih obveznosti in prispevanje v skupno varnost, kolektivno obrambo in solidarnost,

- dinamično in trajno transformacijo oboroženih sil.

Obrambna politika se bo razvijala v okviru treh ključnih področij: na področju splošnih zadev ter na mednarodnem in nacionalnem področju.

Smernice za splošne zadeve se nanašajo na razvoj strategije nacionalne varnosti, redno sodelovanje in obveščanje parlamenta (napotitve oboroženih sil na operacije ipd.), krepitev delovanja Sveta za nacionalno obrambo ter krepitev in spodbuditev varnostne in obrambne kulture $\mathrm{v}$ družbi.

Smernice za nacionalno področje se nanašajo na tri ključna področja, in sicer prispevek obrambe k nacionalni varnosti, organiziranost obrambe in španskih oboroženih sil ter druge prispevke k obrambi, ki zajemajo zagotovitev učinkovite koordinacije javnih in zasebnih sredstev, s katerimi razpolaga Ministrstvo za obrambo za mirovne, humanitarne operacije in operacije $\mathrm{v}$ podporo civilnim oblastem, 
razpoložljivost in ustreznost virov za doseganje potreb nacionalne obrambe ter določitev priprav, razpoložljivost virov in zmogljivosti Civilne garde ${ }^{12}$.

Smernice na mednarodnem področju se nanašajo na spoštovanje določil OZN ter na sodelovanje Španije v njegovih operacijah v podporo miru in zagotavljanja humanitarne pomoči. Španija bo dejavno prispevala tudi k razvoju EVOP prek sodelovanja in obrambnih pobud, s poudarkom na razvoju zmogljivosti. Še naprej bo podpirala transformacijski proces Nata in razvoj zmogljivosti za učinkovito skupno mednarodno odzivanje na sodobne grožnje mednarodni varnosti.

Uresničevanje smernic, zapisanih v direktivi, bo preverjal Svet za nacionalno obrambo. Prek medministrske obrambne komisije bo ustanovil kontrolne mehanizme in predstavil letno poročilo o njeni realizaciji predsedniku vlade.

\subsubsection{Velika Britanija: „A New Strategy for Defence 2009«}

\section{$\underline{\text { A. Oblikovno }}$}

Obrambna strategija Velike Britanije nima izdelane strukture po poglavjih in podpoglavjih, temveč je zapisana v obliki izjave na petih straneh in je javno dostopna. Njen zaupni del podrobneje ureja in usmerja njeno izvajanje na področju planiranja, programiranja in financiranja. V nadaljevanju je analiziran javno dostopni del strategije.

Posamezni odstavki strategije so strukturirani, uvodna dva pojasnjujeta namen in njeno hierarhično umeščenost, časovno omejenost ter hkrati predstavljata povzetek dokumenta in najpomembnejše obrambne cilje, predvsem z vidika vloge in nalog ministrstva za obrambo in oboroženih sil.

Potrebo po sprejetju nove obrambne strategije sta določala dva izvedena Pregleda zmogljivosti (Capability Review). Iz hierarhičnega vidika strategija izhaja iz nacionalnovarnostne strategije in se osredotoča na obdobje naslednjih petih let, in sicer do leta 2014.

Vodilo pri izdelavi strategije je bilo zagotoviti skladno izvajanje aktivnosti v celotnem obrambnem ministrstvu in večje zavedanje glede prioritizacije virov. Strategija naj bi zagotavljala oboroženim silam nadaljnjo podporo, preudarno porabo finančnih sredstev, vnašanje izboljšav v poslovne prakse ter večje doseganje uspešnosti pri zagotavljanju nacionalne obrambe.

Posebnost strategije je, da sta jo odobrila vojak (načelnik obrambnega štaba) in civilna oseba (stalni sekretar) skupaj. Implementacijo strategije na ministrstvu usmerja generalni direktor za strategijo.

\footnotetext{
12 V Španiji je Civilna garda zvezna paravojaška policija ali žandarmerija. Na nacionalnem teritoriju opravlja naloge policije, na mednarodni ravni pa ohranja vojaški status in sodeluje v mednarodnih mirovnih operacijah ter je del EU-žandarmerije.
} 


\section{B. Vsebinsko}

Obrambna strategija podpira obrambni cilj, ki pravi, da se mora z obrambo zagotavljati varnost prebivalcem Velike Britanije in njenim čezmorskim območjem ${ }^{13}$ tudi pred terorizmom ter delovati kot dobronamerna sila, ki sodeluje pri krepitvi mednarodnega miru in stabilnosti.

Skladno z obrambnim ciljem in izhodišči nacionalnovarnostne strategije so $\mathrm{v}$ petletnem obdobju pomembni predvsem ti cilji:

- uspehi operacije Isaf v Afganistanu in drugih mednarodnih operacij in misij,

- izvajati stalne obrambne naloge, vključno z jedrskim odvračanjem pred neposrednimi grožnjami na ozemlju Velike Britanije in njenih čezmorskih območjih,

- učinkovito in uspešno zagotavljanje nacionalne obrambe.

Strategija izpostavlja zlasti te usmeritve na obrambnem področju:

1. povečati podporo operaciji v Afganistanu,

2. slediti uravnoteženosti med programi in viri,

3. zagotavljati sredstva za izvajanje po obsegu manjših, a verjetnih kriznih operacij (npr. v primeru terorizma, za evakuacijo prebivalcev Velike Britanije iz kriznih območij),

4. prilagajati ravni ambicij,

5. razvijati »mehko« moč obrambe - usmerjeno v preprečevanje konfliktov ter večnacionalno delovanje,

6. izboljšati strateško upravljanje obrambe.

\subsubsection{Združene države Amerike: "National Defense Strategy 2008«}

\section{$\underline{\text { A. Oblikovno }}$}

Naziv dokumenta je Nacionalna obrambna strategija, ki obsega 24 strani. V njej je posebej poudarjeno, da je glavna odgovornost vlade zaščititi prebivalce ZDA, kot je opredeljeno v ustavi, ter zavezanost k demokratičnim vrednotam. Strategija še navaja, da uspeh ne bo mogoč s samostojnim delovanjem, temveč le v skupnem sodelovanju s partnerji in zavezniki.

Strategija izhaja iz nacionalnovarnostne strategije, podaja usmeritve za doseganje njenih ciljev ter predstavlja podlago za nacionalno vojaško strategijo. Pri oblikovanju obrambne strategije so se upoštevale tudi izkušnje iz operacij in ugotovitve štiriletnega obrambnega pregleda.

Obrambna strategija predstavlja ključni dokument obrambnega ministrstva v prizadevanjih države pri zagotavljanju trajne varnosti. Poleg tega daje tudi usmeritve ameriškim oboroženim silam za delovanje v vojaških operacijah. Strategija zagotavlja

\footnotetext{
13 Velika Britanija in Argentina sta bili v sporu za suverenost nad Falklandskim otočjem, kar je vodilo v krizo (vojno) med državama leta 1982 z argentinsko invazijo in okupacijo otočja. Po 74-dnevni vojni (ki je uradno sicer ni razglasila nobena stran) si je suverenost nad otočjem izborila Velika Britanija, ki ima vse od takrat to otočje za čezmorsko ozemlje in je strateškega pomena.
} 
okvir za ministrske strateške smernice na področju kriznega planiranja, razvoja oboroženih sil in obveščevalnih zadev.

\section{B. Vsebinsko}

Strategija opisuje prihodnje strateško okolje, ki ga bo vse bolj zaznamoval globalni boj proti ekstremističnim gibanjem. Poleg tega strategija izpostavlja tudi druge neregularne izzive, prizadevanja propadlih držav po pridobitvi jedrskih zmogljivosti za nemiroljubne namene (Iran, Severna Koreja) ter vzpone vojaških sil drugih držav (Kitajska, Rusija), ki bodo imele vpliv na ZDA in evropske zaveznike.

Strategija navaja, da bo ministrstvo v procesu planiranja upoštevalo strateške razvojne trende (energetski viri, podnebje, okolje), ki bodo v kombinaciji s hitrimi družbenimi, kulturnimi in tehnološkimi spremembami povzročali dodatne negotovosti. Zaradi teh globalizacijskih procesov in vse večje svetovne soodvisnosti so postale tudi ZDA vse bolj ranljive za kompleksne krizne pojave. Tem okoliščinam se bo morala prilagajati tudi obrambna politika.

ZDA so vse od konca druge svetovne vojne delovale kot primarna sila za ohranitev mednarodne varnosti in stabilnosti, saj so vodile Zahod v času hladne vojne. Danes imajo ZDA vodilno vlogo v mednarodnih prizadevanjih pri soočanju z nasilnim ekstremizmom, in sicer z vojaškimi, diplomatskimi in gospodarskimi sredstvi. Takšna prizadevanja so podprta $\mathrm{z}$ nacionalnimi interesi ter vizijo priložnosti in blaginje. Za doseganje teh interesov bodo ZDA razvijale vojaške zmogljivosti, oblikovale zavezništva in koalicije, sodelovale in podpirale mednarodne varnostne in gospodarske institucije, uporabljale diplomatska sredstva in mehko uporabo sile za vplivanje na vedenje držav in mednarodnih sistemov ter uporabljale silo, ko bo to treba.

Skladno z usmeritvami nacionalnovarnostne strategije obrambna strategija določa pet ključnih ciljev ministrstva za obrambo, in sicer:

1. obrambo domovine,

2. zmagati v vojni pred nasilnimi ekstremističnimi gibanji,

3. spodbujati varnost - strategija poudarja gradnjo partnerstva kot podlago za dolgoročno varnost,

4. odvračanje (konflikta) - odvračanje temelji na vojaških zmogljivostih (jedrskem orožju, konvencionalnih zmogljivostih, raketni obrambi idr.) z možnostjo »preemptivnega« delovanja,

5. zagotavljanje zmage $\mathrm{v}$ vojnah - najvišja prednost je izboljšanje sposobnosti ameriških oboroženih sil v neregularnem vojskovanju. Zato bodo še naprej razvijale močne konvencionalne sile in jedrske zmogljivosti.

Strategija navaja, da bodo navedeni ključni cilji doseženi s sodelovanjem pomembnih držav pri zagotavljanju mednarodne varnosti in stabilnosti ter spodbujanjem medsebojnega zaupanja, preprečevanjem pridobivanja in uporabe orožij za množično uničevanje, krepitvijo zavezništva in partnerstva, zavarovanjem dostopa do virov in ohranitvijo svobode delovanja ter integracijo in poenotenjem ameriških prizadevanj. 
Področja, ki jim mora obrambno ministrstvo nameniti posebno pozornost in so pomembna za implementacijo ključnih ciljev, so:

- kadri - ZDA si bodo še naprej prizadevale za izboljšanje svojih skupnih sil, vključno z razširitvijo specialnih sil za operacije in kopenskih sil ter razvoj modularnih, prilagodljivih združenih sil,

- strateško komuniciranje - bo imelo pomembno vlogo pri poenotenju pristopa pri zagotavljanju nacionalne varnosti,

- obveščevalne zadeve in distribucija podatkov/informacij - na področju nacionalne varnosti bo poseben poudarek namenjen razvoju zmogljivosti na področju HUMINT za odkrivanje in skrito vključevanje v teroristične mreže ter SIGINT za odkrivanje orožij za množično uničevanje,

- tehnologija in oprema - strategija navaja potrebo po zagotavljanju najsodobnejše vojaške tehnologije in opreme ter izboljšanju nabavnih postopkov in pogojev, ki bodo omogočali pravočasno nabavo ključne opreme in drugih sredstev za oborožene sile,

- organizacija - mrežna povezanost (net-centricity) bo prispevala k večji povezanosti komponent obrambnega ministrstva ter vzpostavljanju stikov med organizacijami s komplementarnimi cilji,

- okrepitev ameriškega pogajalskega sistema - zavezništva in partnerstva so ključna za realizacijo obrambne strategije. Tako si ZDA zagotavljajo potrebne vire, sredstva, znanja, veščine in zmogljivosti, ki jim jih ni treba podvajati,

- viri - krepitev partnerstev, širitev varnostnega sodelovanja ter orodij za graditev partnerskih zmožnosti zahtevajo dodatne vire, ki bodo omogočali zagotavljanje vojaške pripravljenosti,

- oborožene sile - s transformacijo oboroženih sil, ki bodo odražale ekspedicijsko in fleksibilno naravnanost, se bo zagotovila sposobnost uspešnega soočanja z negotovostmi v spreminjajočem se strateškem okolju.

Strategija izpostavlja tudi tveganja, eno izmed njih se nanaša tudi na tveganje, povezano s posrednim pristopom, ki temelji na zmagi v vojni. Američani se namreč močno zavedajo, da se bodo prispevki partnerjev v prihodnjih koalicijskih operacijah spreminjali v številu, strukturi, kompetentnosti in v zmogljivostih. Kljub temu poudarjajo, da vojne $\mathrm{v}$ sodobnem in kompleksnem svetu ni mogoče zmagati brez sodelovanja partnerjev.

\subsection{Primerjalna analiza izbranih držav}

Vse preučevane države upoštevajo hierarhični pristop oblikovanja strateških dokumentov s področja nacionalne varnosti ter smiselno upoštevajo tudi strateške dokumente ključnih mednarodnih organizacij (OZN, Nata, EU ipd.), katerih članice so. Izjema je kanadska obrambna strategija, v kateri je navedeno, da izhaja iz vizije vlade glede dolgoročnega preoblikovanja oboroženih sil, zato dokument vsebuje tudi določene segmente dolgoročnega planskega dokumenta.

Med vsemi preučevanimi dokumenti držav vse države uporabljajo sodobni pristop $\mathrm{k}$ zagotavljanju varnosti in obrambe, izjema je srbska obrambna strategija, ki vključuje 
še konstitutivne elemente delovanja obrambnega sistema. Druge države konstitutivne sestavine in njihova razmerja praviloma opredeljujejo v normativnih aktih. Velika Britanija ima svojo obrambno strategijo zapisano v obliki javno dostopne izjave na petih straneh, njen zaupni del pa obsega podrobnejše usmeritve, ki se nanašajo na planiranje, programiranje in financiranje. Posebnost najdemo tudi v kanadski obrambni strategiji, ki združuje elemente obrambne strategije in dolgoročnega plana. Strategije preučevanih držav veljavnosti dokumenta ne navajajo, razen španske, ki je vezana na mandat vlade, in angleške, ki se ji veljavnost izteče leta 2014.

Smernice in cilji obrambnih politik na obrambnem področju so v vseh državah jasno opredeljeni, izhajajo iz nacionalnovarnostnih interesov in ciljev ter sledijo sosledju od splošnega k posebnemu.

Poudarki obrambnih strategij so tudi na konceptu delovanja obrambnega sistema pri zagotavljanju obrambe države ter vlogi vojaških in civilnih obrambnih zmogljivosti. Vse strategije v ospredje postavljajo tudi pomen skupnega delovanja vojaških in civilnih zmogljivosti v mednarodnih operacijah in na misijah. Delovanje obrambnih sistemov je tesno povezano s sodelovanjem z vlado in vladnimi resorji, nevladnimi akterji, privatnim sektorjem ter obrambno industrijo. V primerjavi z vsemi obrambnimi strategijami le srbska in španska omenjata strukturo in organiziranost obrambnega sistema, ki se deli na vojaško in civilno obrambo, ter vlogo drugih državnih subjektov pri obrambi države.

Vse države izpostavljajo možnosti samostojnega delovanja za zavarovanje nacionalnih interesov, ZDA tudi možnost »preemptivnega« delovanja. Velika Britanija in ZDA izpostavljata možnosti jedrskega odvračanja, Srbija pa edina med vsemi državami še vedno gradi sistem totalne obrambe. Obrambna strategija Češke se vsebinsko velikokrat navezuje na Nato in EU, v ospredje pa postavlja zavedanje o prispevanju v skupno varnost in obrambo v zameno za garancijo kolektivne obrambe in kolektivne varnosti.

Opredeljevanje aktivnosti oboroženih sil v operacijah in njihove ravni delovanja najbolj konkretno opredeljuje češka strategija, medtem ko kanadska, španska in angleška strategija podajajo zgolj usmeritve ali pa izpostavljajo pomen vzpostavljanja zmogljivosti za doseganje ravni delovanja oboroženih sil. V srbski in ameriški strategiji pa to opredeljevanje ni posebej izpostavljeno.

Za implementacijo obrambne politike, zastavljenih ciljev in prioritet so v vseh strategijah izpostavljene potrebe po zagotovitvi in ustrezni porazdelitvi obrambnih virov (kadrov, opreme, financ, infrastrukture). Češka prednostno izpostavlja modernizacijo vojaške opreme in izboljšanje kadrovske politike. Kanada bo na tem področju izvajala izboljšave za zmanjšanje vrzeli v kadrih in opremi, kar poudarja tudi Španija. Velika Britanija se zavzema za preudarnejšo izrabo vseh obrambnih virov ter racionalizacijo izdatkov, ki niso namenjeni za operacije. ZDA se z vidika obrambnih virov zavzema predvsem za izboljšanje delovanja skupnih sil in nabavnih 
postopkov. Kanada, Srbija, Velika Britanija in ZDA posebej izpostavljajo še pomen sodelovanja z obrambno industrijo in pomen področja razvoja in raziskav.

Glede zagotavljanja finančnih sredstev so vse države enotne, da so potrebna ustrezna, zadostna, stabilna in vzdržna finančna sredstva (t. i. usmerjeno investiranje), ki omogočajo razvoj obrambnih zmogljivosti. Kanada izpostavlja zmanjšanje obrambnih izdatkov za osebje (pod $50 \%$ ) in povečanje za investicije in operacije, slednje prek posebnega fonda financiranja, ZDA pa bodo za pridobitev dodatnih finančnih sredstev morale tesneje sodelovati s Kongresom in privatnim sektorjem.

Področje obrambnega planiranja države v svojih strategijah različno obravnavajo, in sicer na nacionalni ravni in v okviru integracije v Natu. Češka področje planiranja omenja v kontekstu članstva $\mathrm{v}$ Natu in zavezanosti k prispevanju v skupno varnost in obrambo v okviru procesa obrambnega planiranja. Tudi Španija obrambno planiranje posredno omenja prek nadaljevanja transformacije oboroženih sil, delovanja v okviru Nata in sodelovanja v operacijah ter zviševanju kriterijev razvoja zmogljivosti in bolj zavezujočih zavez za izvajanje zahtevnejših nalog. Velika Britanija $\mathrm{v}$ javno dostopnem delu planiranje omenja $\mathrm{v}$ povezavi $\mathrm{z}$ izvajanjem operacije $\mathrm{v}$ Afganistanu. V ZDA je planiranje usmerjeno predvsem v zmanjševanje tveganj in negotovosti ter razvoj vojaških zmogljivosti. Prva strategija Kanade je nastala kot rezultat štiriletne vaje s področja planiranja, ki je prispevala k oblikovanju podrobne ravni ambicij sil in določanju prednosti razvoja zmogljivosti. Srbska strategija ima v svoji strukturi posebno poglavje, ki se nanaša na obrambno planiranje. Iz njega je razvidna zavzetost Srbije kot članice PzM za vključitev v Natov sistem obrambnega planiranja, namenjen partnericam, obrambno planiranje pa ima primarno vlogo tudi v upravljanju srbskega obrambnega sistema.

Sklep Izhajajoč iz teoretičnih podlag in hierarhične umeščenosti dokumenta obrambne strategije v hierarhiji strateških dokumentov s področja nacionalne varnosti Republike Slovenije in rezultatov primerjalne analize so v nadaljevanju izpostavljena bistvena priporočila, ki bi lahko koristno prispevala k strukturni in vsebinski kakovosti nastajanja nove Obrambne strategije RS.

Pri izdelavi obrambne strategije je treba slediti hierarhiji strateških dokumentov s področja nacionalne varnosti, kar za Slovenijo pomeni, da mora izhajati iz ReSNV. Če upoštevamo načelo hierarhičnosti in vzajemnosti, bi morala obrambna strategija in ključni strateški planski dokument (Resolucija o splošnem dolgoročnem programu razvoja in opremljanja SV do 2025 - ReSDPRO SV 2025) nastajati vzporedno, saj se z obrambno strategijo med drugim zagotavlja strategija nadaljnjega razvoja obrambnega sistema RS, torej predstavlja tudi izhodišča za strateške planske dokumente. Glede na to, da je ReSDPRO SV 2025 bila sprejeta v Državnem zboru že leta 2010, bo treba pri pisanju nove obrambne strategije posebno pozornost posvetiti usklajenosti dokumenta z ReSNV in ReSDPRO SV 2025. Sledenje hierarhično višjemu dokumentu pa ima do določene mere vpliv tudi na oblikovanje strukture dokumenta. To se bo pri slovenski obrambni strategiji prepoznalo zlasti 
v segmentu organiziranosti in upravljanja obrambnega sistema. Gre za sklop t. i. konstitutivnih vsebin, ki se po izkušnjah drugih, predvsem zahodnoevropskih držav, opredeljujejo v normativnih aktih z obrambnega področja. Opuščanju teh konstitutivnih vsebin, ki bi obrambni strategiji lahko še vidneje pripisali sodobnost in primerljivost z drugimi državami, bo treba nameniti pozornost ob naslednjem oblikovanju ReSNV.

Vsebina obrambne strategije mora slediti načelu od splošnega k posebnemu in temeljiti na celovitem pristopu zagotavljanja obrambe in varnosti države. Obrambna strategija se omejuje na obrambno prvino nacionalne varnosti, zato se mora osredotočiti predvsem na elemente in mehanizme obrambnega podsistema, iz nje pa morata biti razvidna tudi skupno delovanje vseh podsistemov nacionalne varnosti ter navezanost države na sistema kolektivne obrambe in kolektivne varnosti v okviru Nata in EU pri zagotavljanju nacionalne obrambe.

Pri oblikovanju vsebin nove obrambne strategije si je treba prizadevati, da se ohrani njena splošnost, vendar konkretnost glede usmeritev, ciljev in razvoja obrambne politike ter opredeljevanja prednosti in ohrani vsebinska ter vrednostna distinkcija do planskih dokumentov (ReSDPRO SV 2025). S tega vidika tudi podrobne vsebine o ravni delovanja in obrambnem planiranju ne spadajo $\mathrm{v}$ ta dokument.

Iz oblikovnega vidika bi morala biti obrambna strategija pregledna in naj bi obsegala največ 20 strani. Lahko bi vključevala tudi predgovor predsednika vlade ali ministra za obrambo in kazalo.

Med ključne naloge Ministrstva za obrambo v letu 2012 spada dokončanje in sprejem nove Obrambne strategije Republike Slovenije na Vladi RS. Tako bo sklenjena trilogija priprave prenovljenih strateških dokumentov naše države $\mathrm{z}$ obrambnega oziroma nacionalnovarnostnega področja. Kot temeljni strateški dokument na obrambnem področju bo nova Obrambna strategija Republike Slovenije predstavljala podlago za pripravo in dopolnjevanje drugih operativnih in doktrinarnih dokumentov na obrambnem področju ter za normativno, organizacijsko in vsebinsko urejanje vprašanj v zvezi z obrambo Republike Slovenije, kot vhodni dokument v procesu obrambnega planiranja pa bo pomembno vplivala tudi na pripravo novega Srednjeročnega obrambnega programa 2013-2018.

2. Bebler, A. (et al), 1999. Raziskovalna naloga: Hierarhija dokumentov na področju nacionalne varnosti v Republiki Sloveniji. Fakulteta za družbene vede, Inštitut za družbene vede, Obramboslovni raziskovalni center. Ljubljana.

3. Benko, V., 1997. Znanost o mednarodnih odnosih. Fakulteta za družbene vede. Ljubljana.

4. Canada First Defence Strategy, 2006. National Defence Canada. Canada.

5. Davis, P., 1994. New Challenges for Defense Planning. Rand. Santa Monica.

6. Ferfila, B. (et al), 2003. Politics, policy and budgeting: North America Perspectives, Fakulteta za družbene vede. Ljubljana. 
7. Javornik, M. (ur.), 1998. Veliki splošni leksikon: v osmih knjigah. DZS, Ljubljana.

8. National Defense Directive, 01/2008. Consejo De Defensa Nacional. Spain.

9. National Defense Strategy, 2008. Department of Defense, USA.

10. NATO Handbook, 2006. http://www.nato.int, 22. februar 2010.

11. Resolucija o splošnem dolgoročnem programu razvoja in opremljanja Slovenske vojske do leta 2025, 2010. Uradni list RS, št. 99/2010, z dne 7. decembra 2010.

12. Resolucija o strategiji nacionalne varnosti Republike Slovenije, 2010. Uradni list RS, št. 27/2010, z dne 2. aprila 2010.

13. Strategija odbrane Republike Srbije, 2009. Ministarstvo odbrane Republike Srbije, Republika Srbija.

14. Strategija sodelovanja RS v mednarodnih operacijah in misijah. Vlada RS, št. 8710016/2009/7, z dne 12. novembra 2009,

15. Strateški pregled obrambnega resorja 2009, 2009. Ministrstvo za obrambo. Republika Slovenija.

16. The Military Strategy of the Czech Republic, 2008. Approved by the Governmental Resolution of 23rd July 2008, Nr. 907. Czech Republic.

17. Ustava RS. 1992. ČZ Uradni list RS.

18. Yarger, H., 2006. Strategic theory fro the 21st century: The Little Book on Big Strategy. Army War College (U.S.). Strategic Studies Institute.

19. Zakon o obrambi (uradno prečiščeno besedilo), 2004. Uradni list RS, št. 103/2004 z dne 23. septembra 2004, str. 12478 . 